\title{
Assessment of fattening performance and slaughtering characteristics of young bulls from Aberdeen Angus breed, Volyn Meat breed, and Charolais breed
}

\author{
N. P. Svyrydenko*, S. O Kostenko \\ National University of Life and Environmental Sciences of Ukraine \\ *Corresponding author E-mail: natasvyrydenko@gmail.com
}

Received 14.11.2019 Accepted 21.12.2019

\begin{abstract}
This paper deals with the research of special features of fattening and slaughtering qualities of specialized meat cattle bred in Ukraine. It establishes special feature of the cattle growth intensity and development in terms of live weight gain and linear assessment of the exterior in the age from birth to 18 months. It has been established that young bulls of Volyn Meat breed were characterized by a higher slaughter yield of $61.7 \%$. Charolais bulls of the same age had the highest carcass yield of $78.5 \%$. Young Aberdeen Angus cattle had the highest fleshing index of 4.5 compared to 4.3 in bulls of the same age of other breeds.
\end{abstract}

Key words: Cattle; Meat breeds; Young bulls; Weight gain; Slaughtering qualities

\section{Introduction}

In recent years, there have been efforts in the world to increase beef production and improve beef quality through the development of specialized beef cattle breeding (Zubets, Burkat 2005; Bureš, Bartoň, 2018).

Given the wide variety of genotypes of meat cattle used in Ukraine, there is a need for scientific substantiation of the selection of a particular breed with competitive fattening qualities and after-slaughter meat yield characteristics, and assessment of the genetic potential of cattle in the natural and climatic conditions (Shkurin, Timchenko, 2002; Melnyk, 2007)

\section{Material and Methods}

The aim of this paper is to identify the most suitable breed for use in the Polissya zone of Ukraine from among three specialized beef cattle breeds (Aberdeen Angus, Volyn Meat breed, and Charolais).

A total of three xperimental groups of 20 animals each were formed on the basis of zootechnic records from young bulls and heifers of Aberdeen Angus breed, Volyn Meat and Charolais breeds. Peers were selected by age, sex, as well as by live birth weight within the breed. Animals were bred using the traditional beef cattle breeding technology as sucklings from birth to seven months of age, and after weaning in cages of 10-12 heads each in winter and in groups in the pasture in summer. Feeding was balanced and based on diets developed in the farm. Own-produced fodder, which was typical for the given natural and climatic zone, was used. All the fodder given during the day was completely eaten up. Fodder consumption was determined based on the group records. In order to study the growth dynamics, the animals were weighed before feeding in the morning. The following was calculated on the basis of the live weight indicators obtained:

The absolute live weight gain, average daily weight gain and relative weight gain by the common formulas.

In order to study more profound changes taking place in the body of animals in the course of growth under the influence of genotype and phenotype factors, control slaughter should be performed (Zubets and Melnyk, 1997).

3 young bulls, most typical for the particular breed, were selected from each group for the slaughter at the age of 18 months. The following indicators were taken into account at the slaughter: the change in the live weight, pre-slaughter live weight, weight of the hot and cold carcasses, weight of internal fat, internal organs, skin.

To assess the carcass and round fleshiness, the following was measured after 24-hour maturing in the refrigerator: carcass length, round length and circumference. The carcass fleshiness coefficient $\left(\mathrm{K}_{1}\right)$ and the round fleshiness coefficient $\left(\mathrm{K}_{2}\right)$ were calculated on the basis of these indicators by the following formulas:

Cold right half-carcasses were boned in order to study the morphological composition of the carcasses of young bulls of different breeds. The absolute and relative content of boneless, bones, fat, gristles and tendons in a carcass were determined.

Based on the data obtained, the following main post-slaughter indicators were calculated: carcass slaughter yield, boneless meat yield, fleshiness index. All values in table presented as mean and standard deviation.

\section{Results and Discussion}

The difference between the breeds during the entire the breeding period was established based on the analysis of the of live weight dynamics (Table 1). Charolais bulls had the largest live weight at birth, while Aberdeen Angus and Volyn Meat breed bulls were inferior by this indicator. During the suckling period, the live weight of the experimental young stock increased significantly, which testified to a good milk yield of their mothers. 
Table 1. Live weight dynamics of experimental young bulls.

Animal age

New-borns

210 days

6 months

9 months

12 months

15 months

18 months

Here and further * $P>0.95 ; * * P>0.99 ; * * * \quad P>0.999$

\section{Aberdeen Angus (kg)}

$$
\begin{aligned}
& 28.4 \pm 0.59^{* * *} \\
& 202.7 \pm 4.00^{* * *} \\
& 179.8 \pm 3.50^{* * *} \\
& 244.9 \pm 4.17^{* * *} \\
& 316.6 \pm 5.44^{* * *} \\
& 394.5 \pm 6.84^{* * *} \\
& 463.0 \pm 7.91^{* * *}
\end{aligned}
$$

\section{Breeds \\ Volyn Meat (kg)}

$27.6 \pm 0.66$

$216.2 \pm 3.43^{*}$

$191.4 \pm 3.02^{*}$

$263.2 \pm 3.72^{* *}$

$336.4 \pm 4.59^{*}$

$417.2 \pm 5.93^{* *}$

$486.7 \pm 7.13^{* * *}$

\section{Charolais}

$29.3 \pm 0.90$

$230.5 \pm 4.00$

$204.1 \pm 3.52$

$279.7 \pm 4.16$

$355.6 \pm 5.04$

$441.8 \pm 6.17$

$531.4 \pm 7.66$

Calves in Group III had the greatest live weight at the age of 6 months, and surpassed the calves of the same age in Groups I and II with a significant difference of $24.3 \mathrm{~kg}(P>0.01)$ and $12.7 \mathrm{~kg}(P>0.10)$ in young bulls and $28.2 \mathrm{~kg}(P>0.01)$ and $18 \mathrm{~kg}(P>0.01)$ in heifers. By slaughter age (18 months), the live weight of young bull by groups was as follows: Aberdeen Angus - $463 \mathrm{~kg}$, Volyn Meat breed $-487 \mathrm{~kg}$, Charolais - $531 \mathrm{~kg}$, there were especially heavy animals in all experimental groups before the slaughter.

The advantages of Charolais cattle are observed throughout the breeding period, which is a characteristic feature of this breed. The average daily weight gains of Aberdeen Angus and Volyn Meat breeds has a tendency to increase (Table 2) until the age of 15 months, and then there is a slight decrease, unlike the peers of Charolais breeds, whose average daily weight gains continue to grow, which testifies to earlier maturity of the animals of Groups I and II.

Table 2. Daily weight gain dynamic of young bulls.

\begin{tabular}{cccc}
\hline Age periods, months & Aberdeen Angus (g) & $\begin{array}{c}\text { Breeds } \\
\text { Volyn Meat (g) }\end{array}$ & Charolais (g) \\
$0-6$ & $830^{* * *}$ & $898^{*}$ & 958 \\
$6-9$ & $714^{* * *}$ & $787^{*}$ & 830 \\
$9-12$ & $786^{*}$ & 803 & 832 \\
$12-15$ & $855^{* * *}$ & $886^{*}$ & 945 \\
$15-18$ & $752^{* *}$ & $763^{* * *}$ & 982 \\
$0-18$ & $795^{* * *}$ & $840^{* * *}$ & 918 \\
\hline
\end{tabular}

The results of our research show that Charolais young bulls had the highest average daily weight gains. The difference by this indicator from birth to the age of 6 months between the peers of Groups III and I was $120 \mathrm{~g}$ (P>0.01), between Groups III and II $60 \mathrm{~g}(P>0,10)$; in the age from 6 to 9 months - $116 \mathrm{~g}(P>0,01)$ and $43 \mathrm{~g}(P>0,10)$; in the age from 9 to 12 months - $46 \mathrm{~g}$ $(P>0,10)$ and $29 \mathrm{~g}$; in the age from 12 to 15 months $-90 \mathrm{~g}(P>0,01)$ and $59 \mathrm{~g}(P>0,10)$; in the age from 15 to 18 months - $123 \mathrm{~g}$ $(P>0.01)$ and $219 \mathrm{~g}(\mathrm{P}>0.01)$.

The difference in favour of Charolais breed, both in terms of live weight and average daily weight gain, compared to Aberdeen Angus and Volyn beat cattle was highly probable. The greatest increase in absolute weight gains of all animals was observed from birth to the age of 6 months. During the entire breeding period, the Charolais bulls and heifers surpassed the Aberdeen Angus peers by 67.4 and $63.4 \mathrm{~kg}$, and Volyn Meat breed peers by 42.9 and $44.3 \mathrm{~kg}$, respectively (Table 3).

Table 3. Absolute weight gain dynamic of young stock.

Age periods, months

\begin{tabular}{cccc}
\multicolumn{9}{c}{ Young bulls Ig) } \\
$0-6$ & $151.4 \pm 3.29^{* * *}$ & $163.8 \pm 2.76^{*}$ & $174.8 \pm 3.02$ \\
$6-9$ & $65.1 \pm 0.8 \pm 9^{* * *}$ & $71.8 \pm 1.23$ & $75.7 \pm 1.18$ \\
$9-12$ & $71.7 \pm 1.41^{*}$ & $73.2 \pm 1.32^{*}$ & $75.9 \pm 1.21$ \\
$12-15$ & $77.9 \pm 1.57^{* * *}$ & $80.8 \pm 1.80^{* * *}$ & $86.2 \pm 1.23$ \\
$15-18$ & $68.5 \pm 1.30^{* * *}$ & $69.6 \pm 1.77^{* * *}$ & $89.6 \pm 1.79$ \\
$0-18$ & $434.7 \pm 7.72^{* * *}$ & $459.2 \pm 6.79^{* * *}$ & $502.1 \pm 6.95$ \\
\hline
\end{tabular}

\section{Breeds \\ Volyn Meat Charolais}

Young bulls Ig)

The absolute and average daily growth gains do not characterize the growth intensity of cattle as they do not reflect the correlation between the body weight increase of the animal and the growth rate. In case of respectively the same growth rates of two animals of different live weights, their growth intensity will be different. The data provided (Table 4) indicate that the highest relative weight gains of young bulls were observed during the suckling period. This indicator of cattle in all groups decreased with age. 
Table 4. Relative growth rate of young stock.

\begin{tabular}{cccc}
\hline $\begin{array}{c}\text { Growth periods, } \\
\text { months }\end{array}$ & Aberdeen Angus & $\begin{array}{c}\text { Breeds } \\
\text { Volyn Meat }\end{array}$ & Charolais \\
$0-6$ & \multicolumn{2}{c}{ Young bulls (\%) } & \\
$6-9$ & 145.4 & 149.6 & 149.9 \\
$9-12$ & 30.8 & 31.6 & 23.3 \\
$12-15$ & 25.5 & 24.4 & 21.6 \\
$15-18$ & 21.9 & 21.4 & 18.4 \\
$0-18$ & 16.0 & 15.4 & 179.2 \\
\hline
\end{tabular}

Animals from all experimental groups demonstrated a sufficiently high level of growth and development. They met the target breed standards in terms of live weight. According to the Meat Cattle Judgement Instruction, the Aberdeen Angus young stock meets the requirements of the elite record class, and young bulls of Volyn meet Charolais breeds meet the requirements of the elite class.

\section{Slaughtering qualities}

Different breeds of animals have different economic and biological features that were imparted to them in the process of their creation by selection. The size and quality of meat yield are determined by the ability of animals to use nutrients from the fodder to develop of muscle and fat tissues (Pesonen et al., 2015; Jukna et al., 2017). When specialized meat breeds were created, the aim was to obtain animals with well-developed muscular tissues that would have a wide and deep chest and well-rounded legs. Widebodied meat animals have a high meat yield (Stimbirys et al., 2013).

Cattle meat yield is formed in the process of individual development of the body under the influence of hereditary and environmental factors, the most important of which are the feeding and keeping conditions. To study more detailed changes taking place in the animal body, a control slaughter is conducted (Nogalski et al., 2017). The main indicators after the slaughter include the weight of the carcass, the slaughter yield, the carcass yield and others that are closely related to the live weight of the experimental animals. Currently, the selection of meet cattle is focused on obtaining heavy carcasses without excessive fat content and moderate bone content, which is primarily due to the rapid growth of animals (Zubets and Melnyk, 1997). Carcasses with a relatively high weight were obtained in our research (Table 5) due to a high growth rate of experimental animals at a young age. It was established following the research that the highest pre-slaughtered live weight was observed among Charolais young bulls (Table 5), from which the heaviest carcasses $(277.1 \mathrm{~kg}$ ) were obtained. A higher weight of hot carcass, by $14.4 \mathrm{~kg}$ on average, was obtained in Group II of the Aberdeen Angus breeds and Volyn Meat young stock, despite the fact that their pre-slaughter live weight was the same. The difference in the internal fat content in carcasses of cattle of all groups was not significant $-0.1-0.2 \%$, which testifies to the ability of animals to build up muscular tissues for a long time without excessive fat depositing.

Slaughter yield is one of the main indicators of animal meat yield records. Unlike assessment by live weight, the slaughter yield reflects the proportions between the body parts of the animal. Its value shows the correlation of the weight of the carcass and fat with the weight of other parts, i.e. the head, extremities, internal organs, skin. The heavier the carcass, the higher the slaughter yield, the smaller the proportion of inedible parts, the better meat yield of the animal (Pesonen et al., 2015).

Table 5. Slaughtering qualities of meat breeders in the age of 18 months $(n=3)$.

Indicators

Pre-slaughter live weight, $\mathrm{kg}$

Hot carcase weight, kg

Interior fat weight, $\mathrm{kg}$

Interior fat yield, \%

Slaughter weight, kg

Slaughter yield

Carcass yield, \%
Group I

$$
\begin{gathered}
440.9 \pm 14.25 \\
254.2 \pm 13.85 \\
4.6 \pm 0.88 \\
1.0 \pm 0.10 \\
258.8 \pm 14.42 \\
58.6 \pm 1.68 \\
57.6 \pm 1.60
\end{gathered}
$$

\section{Group II}

$$
\begin{gathered}
440.9 \pm 5.78 \\
268.4 \pm 3.57 \\
3.8 \pm 0.46 \\
0.9 \pm 0.09 \\
272.2 \pm 3.94 \\
61.7 \pm 0.28 \\
60.9 \pm 0.31
\end{gathered}
$$

\section{Group III}

$474.6 \pm 33.59$

$277.7 \pm 23.12$

$5.1 \pm 0.72$

$1.1 \pm 0.08$

$282.8 \pm 23.85$

$59.5 \pm 0.92$

$58.4 \pm 0.84$

The slaughter and carcass yields of the breeds researched were high enough. This indicators had the highest value in animals of the Volyn Meat breed, which outweighed the peers in Groups I and III in terms of carcass yield by 3.3-2.5\%, respectively, and as for the slaughter yield, the difference in favour of the animals in Group II was 3.1-2.2\%.

Analysis of the morphological composition of carcasses of Charolais cattle indicates a favourable ratio of individual components: muscle tissues $-77 \%$, intramuscular fat $-4.4 \%$, bones $-18.6 \%$. It is $4.25 \mathrm{~kg}$ of boneless meet per $1 \mathrm{~kg}$ of bones. The carcass fleshiness coefficient $\left(K_{1}\right)$ and the round fleshiness coefficient $\left(K_{2}\right)$, calculated on the basis of measurements, and the area of the "muscle eye" complement the carcass characteristics. There is no significant difference in the carcass length between animals of different breeds (Table 6). 
Table 6. Carcass fleshiness of young bulls of different breeds.

\section{Indicator}

Carcase length

Round length, $\mathrm{cm}$

Round circumference, $\mathrm{cm}$

Carcass fleshiness coefficient $\left(K_{1}\right), \%$

Round fleshiness coefficient $\left(K_{2}\right), \%$

"Muscle eye" area, $\mathrm{cm}^{2}$

\section{I}

$138.3 \pm 0.88$
$92.0 \pm 1.53$
$97.0 \pm 3.06$
$180.7 \pm 10.54$
$105.6 \pm 4.41$
$88.5 \pm 3.23$

Cattle groups

II

III

$138.0 \pm 1.73$

$139.0 \pm 3.21$

$94.3 \pm 0.88 \quad 95.7 \pm 2.96$

$89.8 \pm 3.17 \quad 99.3 \pm 2.73$

$191.0 \pm 2.61 \quad 195.7 \pm 12.22$

$95.3 \pm 3.98 \quad 103.9 \pm 1.52$

$89.8 \pm 3.40 \quad 101.5 \pm 8.80$

Table 7. Morphological composition of right half-carcass.

\section{Indicator}

Weight of cold right half-carcass, $\mathrm{kg}$

of which: boneless meat, $\mathrm{kg}$

$\%$

bones, $\mathrm{kg}$

$\%$

fat, $\mathrm{kg}$

$\%$

Gristles and tendons, $\mathrm{kg}$

$\%$
Aberdeen Angus

$$
\begin{gathered}
124.3 \pm 6.98 \\
97.0 \pm 6.42 \\
78 \\
22.6 \pm 1.16 \\
18 \\
1.7 \pm 0.12 \\
1.4 \\
4.0 \pm 0.12 \\
3.2
\end{gathered}
$$

\section{Breeds}

Volyn Meat

$131.5 \pm 1.97$

$102.3 \pm 2.51$

77.8

$23.7 \pm 0.69$

18

$1.8 \pm 0.15$

1.4

$3.7 \pm 0.62$

2.8
Charolais

$135.7 \pm 11.53$

$106.5 \pm 9.31$

78.5

$25.0 \pm 1.88$

18.5

$0.9 \pm 0.15$

0.7

$3.3 \pm 0.35$

2.4

Fleshing index, kg

$4.5 \pm 0.3$

$4.3 \pm 0.15$

$4.3 \pm 0.06$

The round length of Charolais young stock was 3.7 and $1.4 \mathrm{~cm}$ longer than the peers of Aberdeen Angus and Volyn Meat breeds. There was a similar tendency in terms of the round circumference, the advantage of young bulls in Group III was 2.3 and $9.4 \mathrm{~cm}$. The highest carcass fleshiness coefficient was demonstrated by Charolais cattle, i.e. $15 \%$ and $5 \%$ higher than in Aberdeen Angus and Volyn Meat cattle, respectively. The "muscle cell" area of animals of all experimental groups was high and met the requirements of world standards. The minimum requirements for its area in carcasses of specialized meat breeds is $74.8-82.6 \mathrm{~cm}^{2}$. According to G. Minish and D. Fox, the "muscle cell" area characterizes the content of muscle tissue in the carcass. Thus, it had the highest value in Charolais young bulls, and slightly lower (by 11.74\%) in Volyn Meat and (by 13.04\%) Aberdeen-Angus breeds. An important indicator characterizing the quality of carcasses is their morphological composition. The most desirable animals are those giving carcasses with a high boneless meat content and a relatively low content of fat, bones, gristles and tendons. In order to get a better idea of the meat quality of the experimental animals, right half-carcasses of the animals were boned. It was established that Charolais breed had the highest boneless meet content (Table 7, Figure 1) in the half-carcass, which outweighed the peers Groups I and II by 9.5 and $4.2 \mathrm{~kg}$, respectively. In terms of the relative boneless meat yield, the difference between animals was $0.5 \%$ in Groups III and I, and $0.7 \%$ in Groups III and II.

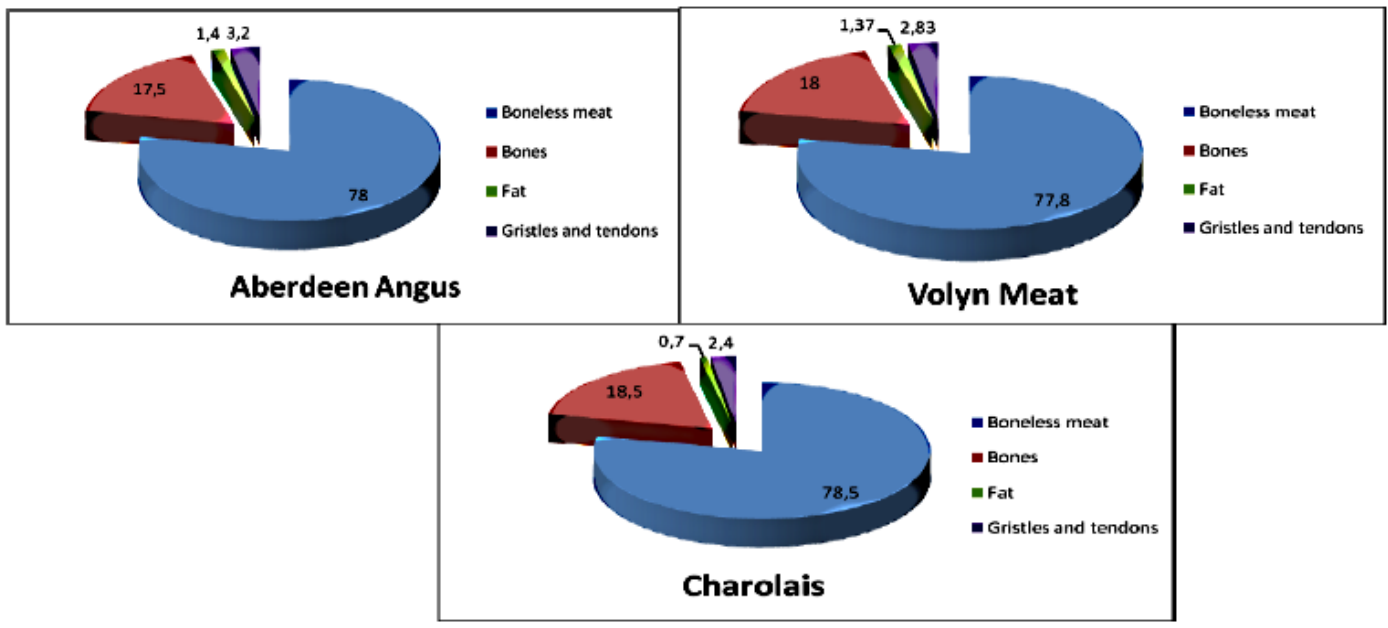

Figure 1. Morphological composition of half-carcasses. 
The carcass fat content of animals in Groups I and II was almost the same (1.37-1.40\%), and that of the peers in Group III was only $0.7 \%$, which is a biological feature of this breed. Aberdeen Angus cattle had $4.5 \mathrm{~kg}$ of boneless meet per $1 \mathrm{~kg}$ of bones, which is $0.2 \mathrm{~kg}$ more than jn peers of Volyn Meat and Charolais breeds.

This paper scientifically substantiates the feasibility of breeding animals of Aberdeen Angus, Volyn Meat and Charolais brees in the Polissya zone of Ukraine. When animals are bred using the traditional beef cattle breeding technology, the live weight of Aberdeen Anguski bulls at the age of 18 months was $463 \mathrm{~kg}$, Volyn Meat breed - $487 \mathrm{~kg}$, and Charolais - $531 \mathrm{~kg}$. The average daily weight gains by groups were 795, 839 and $918 \mathrm{~g}$, respectively. Carcasses with a relatively high weight were obtained due to a high growth rate of experimental animals at a young age. The highest pre-slaughtered live weight was observed among Charolais young bulls, from which the heaviest carcasses $(277.1 \mathrm{~kg})$ were obtained. A higher weight of hot carcass, by $14.4 \mathrm{~kg}$ on average, was obtained in Group II of the Aberdeen Angus breeds and Volyn Meat young stock, despite the fact that their pre-slaughter live weight was the same.

\section{Conclusion}

Young bulls of Volyn Meat breed were characterized by a higher slaughter yield of $61.7 \%$. Charolais bulls of the same age had the highest carcass yield of $78.5 \%$. Young Aberdeen Angus cattle had the highest fleshing index of 4.5 compared to 4.3 in bulls of the same age of other breeds. It should be noted that the highest absolute weight of the most valuable beef piece (hip) was obtained from animals of the Charolais breed, which is 5.2 and $7.4 \mathrm{~kg}$ more in comparison with peers of Volyn Meat and Aberdeen Angus breeds. Charolais animals also had the highest the content of fillets, which is no less nutritionally valuable piece. The animals in Group III had the highest content of the first grade beef $-31.8 \%$, the difference compared to the animals in Groups I and II was 4.7 and $5 \mathrm{~kg}$, respectively.

\section{References}

Bures D., Barton L. (2018). Performance, carcass traits and meat quality of Aberdeen Angus, Gascon, Holstein and Fleckvieh finishing bulls. Livestock Science, 214, 231-237. https://doi.org/10.1016/j.livsci.2018.06.017

Guzeev, I.V., Bogdanov, G.O., Melnik, Yu.F. (2005). Strategy of development of meat cattle breeding in Ukraine. Kyiv: Agrarian Science (in Ukrainian).

Jukna V., Jukna C., Prusevičius V., Meškinytè-Kaušilienè E., Pečiulaitienè N. (2017). Meat quality of different beef cattle breeds fed high energy forage. Zemdirbyste-Agriculture, 104(3), 277-282 DOI 10.13080/z-a.2017.104.035/

Melnik Y.F. (2006). Fertility properties of livestock of planned breeds of Ukraine. Visnyk of Sumy State Agrarian University, 10(11), 4-8.

Melnyk Yu.F. (2007). Estimation of slaughter quality of bovine animals of dairy, combined and meat breeds of Ukraine. Tavricheskii Scientific Bulletin, 54, 93-99 (in Ukrainian).

Nogalski, Z., Pogorzelska-Przybyłek, P., Sobczuk-Szul, M., Nogalska, A., Modzelewska-Kapituła, M., \& Purwin, C. (2017). Carcass characteristics and meat quality of bulls and steers slaughtered at two different ages. Italian Journal of Animal Science, 17(2), 279288. doi:10.1080/1828051x.2017.1383861

Pesonen M., Huuskonen A. (2015). Production, carcass characteristic and valuable cuts of beef breed bulls and heifers in Finnish beef cattle population. Agricultural and food science, 24, 164-172.

Shkurin G.T., Timchenko O.G., Vdovichenko Yu.V. (2002). Slaughter quality of cattle. Kyiv: Agrarian Science (in Ukrainian). Stimbirys A., Shernienel L., Prusevichus V., Jukna V., Shimkus A., Shimkiene A. (2016). The influence of different factors on bull carcass conformation class in Lithuania. Bulgarian Journal of Agricultural Science, 22(4), 627-634

Zubets MV, Melnyk Yu.F., Efimenko M.Ya (1997). Genetics, selection and biotechnology in cattle breeding. Kyiv: BMT (in Ukrainian).

\section{Citation:}

Svyrydenko, N.P., Kostenko, S.O. (2019). Assessment of fattening performance and slaughtering characteristics of young bulls from Aberdeen Angus breed, Volyn Meat breed, and Charolais breed. Ukrainian Journal of Ecology, 9(4), 641-645.

(cc) $\mathrm{EY}$ This work is licensed under a Creative Commons Attribution 4.0. License 